\title{
DISTRIBUTION AND CHARACTERIZATION OF LESSEPSIAN MIGRANT FISHES ALONG THE COAST OF LIBYA
}

\author{
Esmaile A. SHAKMAN* and Ragnar KINZELBACH \\ Allgemeine und Spezielle Zoologie, Universität Rostock, Germany
}

Shakman E.A., Kinzelbach R. 2007. Distribution and characterization of Lessepsian migrant fishes along the coast of Libya. Acta Ichthyol. Piscat. 37 (1): 7-15.

Background. The Lessepsian migrant ichthyofauna along the approximately $2000 \mathrm{~km}$ of the Libyan coastline has been poorly known. A comprehensive study, addressing this issue, was needed and therefore the presently reported research project is intended to close the gap, through identifying the fish species and assessing their distribution.

Materials and Methods. The catches of commercial fisheries vessels were monitored and examined in a standardized procedure between January 2005 and March 2006. The project covered a total of 4273 specimens, comprising 1901 specimens of Siganus luridus, 1885 specimens of Siganus rivulatus, and 487 specimens of fourteen other Lessepsian fish species.

Results. Sixteen Lessepsian fish species, representing 14 families, were recently found along the Libyan coast, two of which are considered to be first records for Libya: Herklotsichthys punctatus (Rüppell, 1837) and Liza carinata (Valenciennes, 1836). Approximately 50\% of the immigrants were found along the entire stretch of the Libyan coast, $12.5 \%$ in the east and central regions, and $37.5 \%$ were restricted to the eastern part of the Libyan coast. All were found in the coastal area (1-50 m depth), $12.5 \%$ on the vegetation, $31.25 \%$ on sandy bottoms, $12.5 \%$ on rocks, while the majority of them $(43.75 \%)$ were pelagic. Regarding the size, $75 \%$ were medium, $18.75 \%$ large, and $6.25 \%$ were categorized as small.

Conclusions. The north African coast (west of the Nile delta) - compared with the Levantine- and Anatolian coast of the Mediterranean Sea - was considered to be settled by immigrants from the Red Sea with some delay, due to sea currents. If so, this situation has changed meanwhile at least for fishes. More than $37 \%$ of the recorded Lessepsian fish species are of commercial value, especially rabbitfish (Siganus spp.). The future research should be focussed on monitoring the stocks, especially of the commercially valuable species, regarding the biology and ecology of the Lessepsian migrants. Also, possible further additions to the fish fauna, by new invaders, should be recorded.

Keywords: biogeography, bioinvasions, Libya, Lessepsian migration, marine fish

\section{INTRODUCTION}

The term "Lessepsian migration" was coined by Por (1978) for the migration of organisms from the Red Sea into the eastern Mediterranean through the Suez Canal. Many species, which were able to adapt rapidly to the new environment, spread into the Mediterranean and established new populations. Information on the comparative life histories of the immigrants is necessary (a) for an understanding of the selective mechanisms controlling the passage through the Suez Canal, (b) for an assessment of the adaptive changes of the newly established "neopopulations", and (c) for an evaluation of the extensive ecological changes which invading species may produce in their new areas of distribution (Ben-Tuvia 1978). The number of Lessepsian migrant species exceeds by far the number of species, which have passed from the Mediterranean into the Red Sea; these are named anti-Lessepsian migrants (Por 1978).

The fish fauna of the Mediterranean has already undergone considerable change, as can be illustrated by the following selected case studies. Papaconstantinou (1990) reported that 11 species had reached the Aegean Islands (Dodecanese, Cyclades) through swimming along the coast of Anatolia. Twenty-two Lessepsian fish species live on the coasts of the eastern Mediterranean- and Aegean seas, with some of them becoming commercially important (Torcu and Mater 2000). In 2002, thirty-three Lessepsian fish species were documented on the Anatolian coast (Bilecenoglu and Taşkavak 2002). For the Egyptian coast, several authors have recorded Lessepsian

\footnotetext{
* Correspondence: Mr. Esmaile A. Shakman, Allgemeine und Spezielle Zoologie, Universität Rostock, Universitätsplatz 2, D-18055 Rostock, Germany, e-mail:shugmanism@yahoo.com
} 
fish species (Ben-Tuvia 1976, El-Sayed 1994). Two Lessepsian fish species were recorded in Italy: Siganus luridus (Rüppell, 1829) appeared along the shallow waters of the Pelagic Islands (Azzurro and Andaloro 2004), whilst Fistularia commersonii Rüppell, 1838 was recorded on the eastern coast of Lampedusa (Azzurro et al. 2004). Ktari and Boualal (1971) reported S. luridus for the first time on the Tunisian coast. In 1974, S. luridus and S. rivulatus Forsskål 1775 were recorded for the first time in the Gulf of Gabes (Ktari and Ktari 1974). After that, six Indo-Pacific fish species were recorded in Tunisian waters as newcomers (Parexocoetus mento (Valenciennes, 1847); Pempheris vanicolensis Cuvier, 1831; Stephanolepis diaspros Fraser-Brunner, 1940; S. luridus; S. rivulatus; and Priacanthus hamrur (Forsskål 1775)) (Bradai et al. 2004). The bluespotted cornetfish, F. commersonii, was also recorded along the Tunisian coast (Ben-Souissi et al. 2004). In the Adriatic Sea, Sphyraena pinguis Günther, 1874 was recorded in 2001 (Pallaoro and Dulčić 2001), and afterwards $S$. rivulatus was recorded for the first time in the same area (Dulcic and Pallaoro 2004). The silverstripe blaasop, Lagocephalus sceleratus (Gmelin, 1789), has become an abundant species in the eastern Mediterranean, immediately after its first record (Akyol et al. 2005, Bilecenoglu et al. 2006). More recently, the following alien species were included to Mediterranean ichthyofauna; Japanese threadfin bream, Nemipterus japonicus (Bloch, 1791); teira batfish, Platax teira (Forsskål, 1775); peacock wrasse, Iniistius pavo (Valenciennes, 1840); Red Sea goatfish, Parupeneus forsskali (Fourmanoir et Guézé, 1976); and Indian scad, Decapterus russelli (Rüppell, 1830) (cf. Bilecenoglu and Kaya 2006, Çinar et al. 2006, Corsini et al. 2006, Golani 2006, Golani and Sonin 2006).

Although it is clear that migrant Lessepsian fish species have had an enormous impact on the eastern Mediterranean ecosystem, there has been no thorough study to assess this impact (Golani 2002). Many Lessepsian fish species have been recorded in Libyan waters (Stirn 1970, Zupanovic and El-Buni 1982, Al-Hassan and El-Silini 1999, Ben-Abdallah et al. 2005, Shakman and Kinzelbach 2006, Shakman and Kinzelbach 2007). There is no comprehensive study of the Lessepsian marine species in this area, particularly of the fish species, and so the objectives of this paper are to present the distribution and characterization of fish species along the almost $2000 \mathrm{~km}$ of Libyan coast and a general contribution to knowledge of exotic marine fish species in the Mediterranean Sea.

\section{MATERIALS AND METHODS}

This study was carried out on samples collected between January 2005 and March 2006 along the Libyan coast at the depths of $1-50 \mathrm{~m}$. The pelagic and benthic samples were collected with a trammel net (inner mesh $26 \mathrm{~mm}$, outer mesh $120 \mathrm{~mm}$ ). The study area was divided to three main regions according to topography and environment (east region, Sirt Gulf, west region). Two sites were selected in the east region (Tubruk, Benghazi), one site in the Sirt Gulf (Musrata), and two sites in the west region

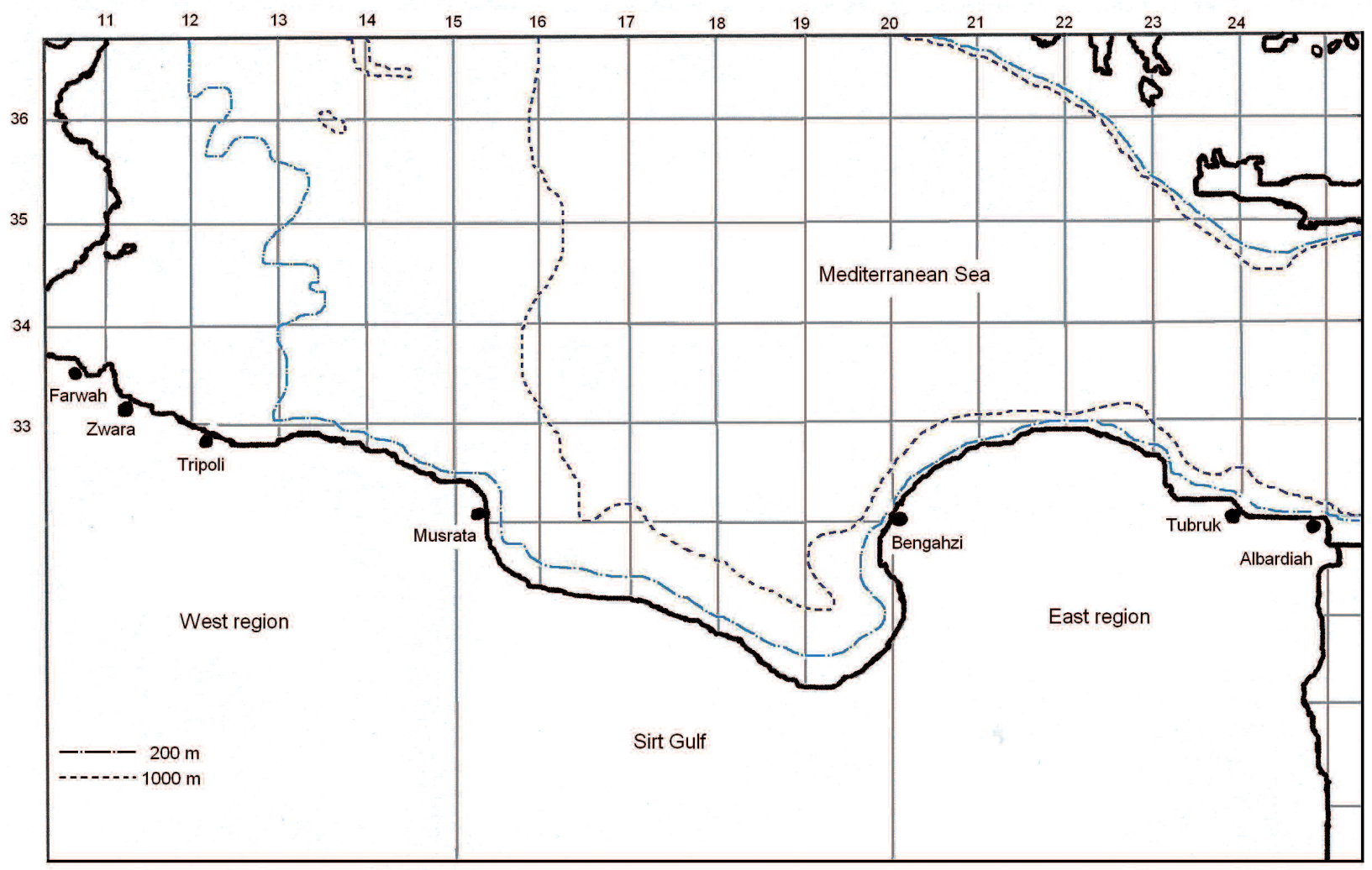

Fig. 1. Map of the Libyan coast, showing cities adjacent to the sampling sites 


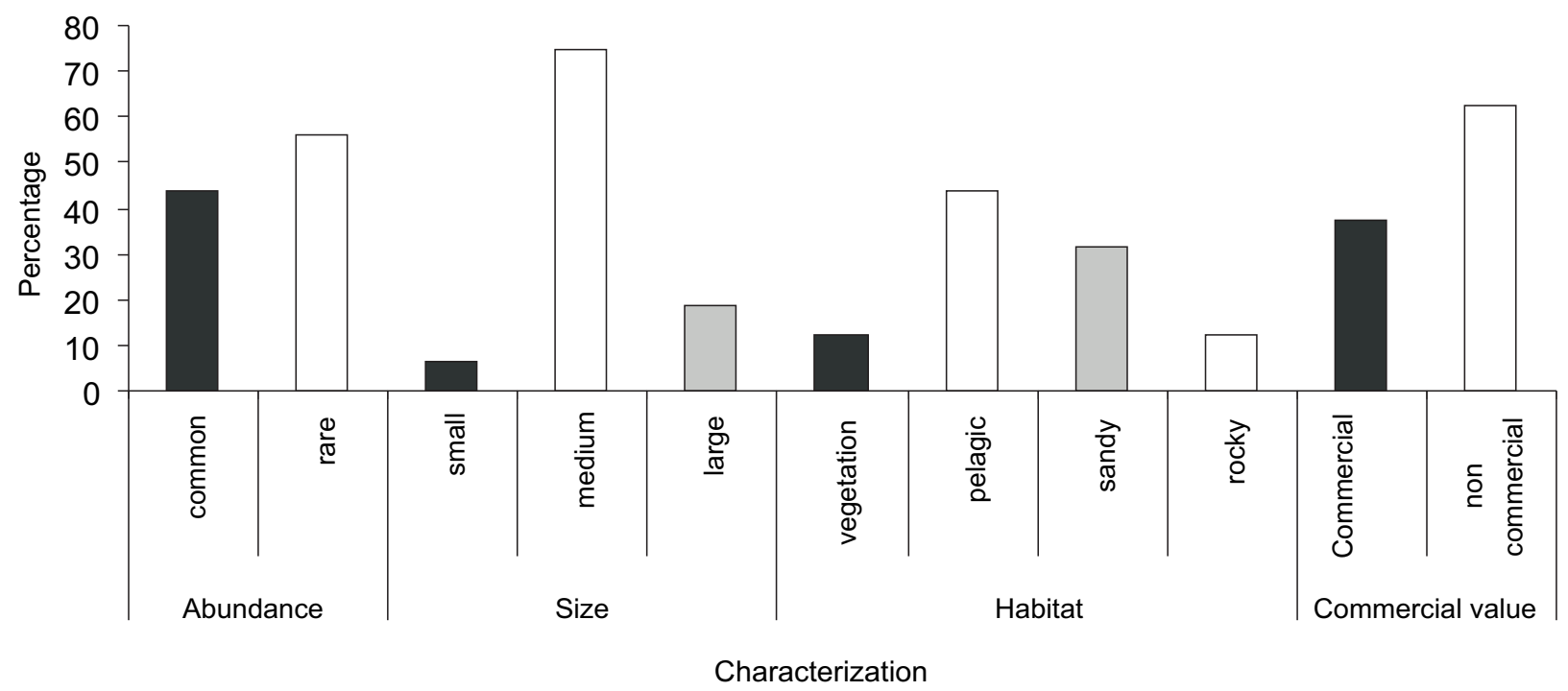

Fig. 2. Characterization of Lessepsian fish species along the Libyan coast

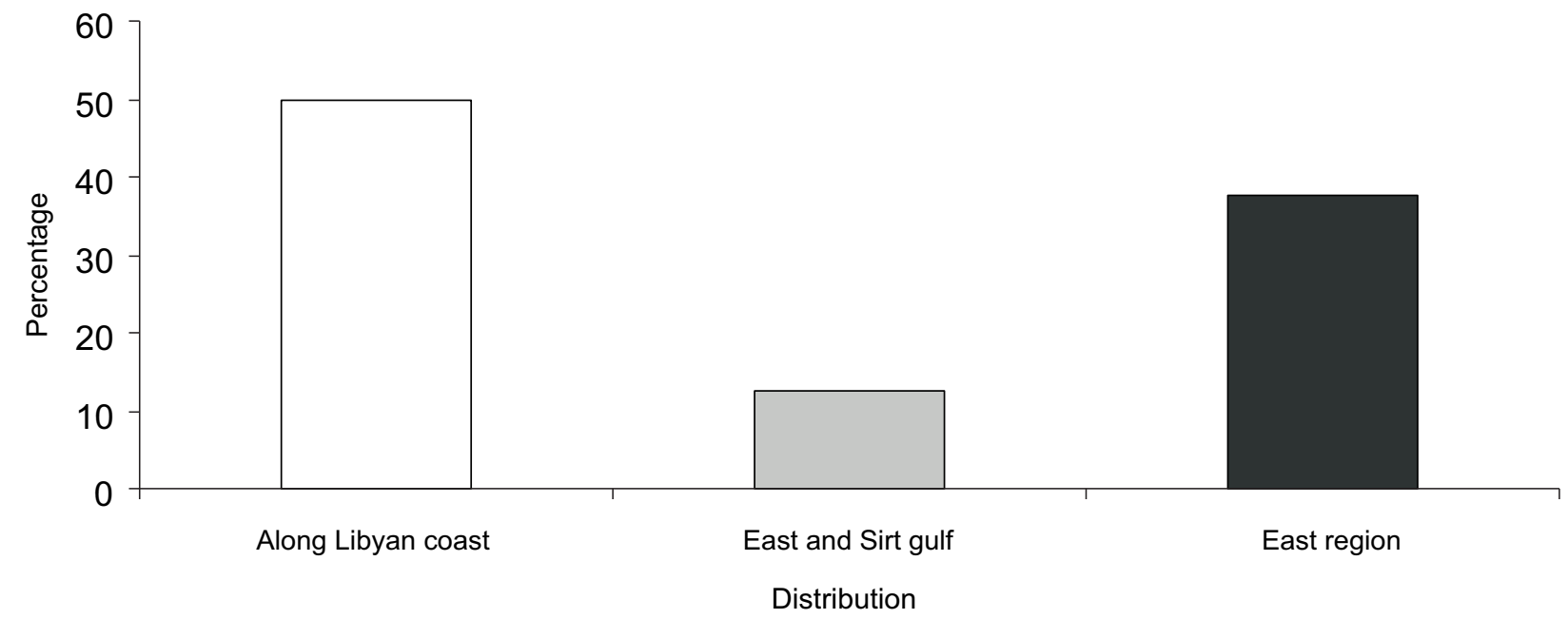

Fig. 3. Distribution of Lessepsian fish species along the Libyan coast

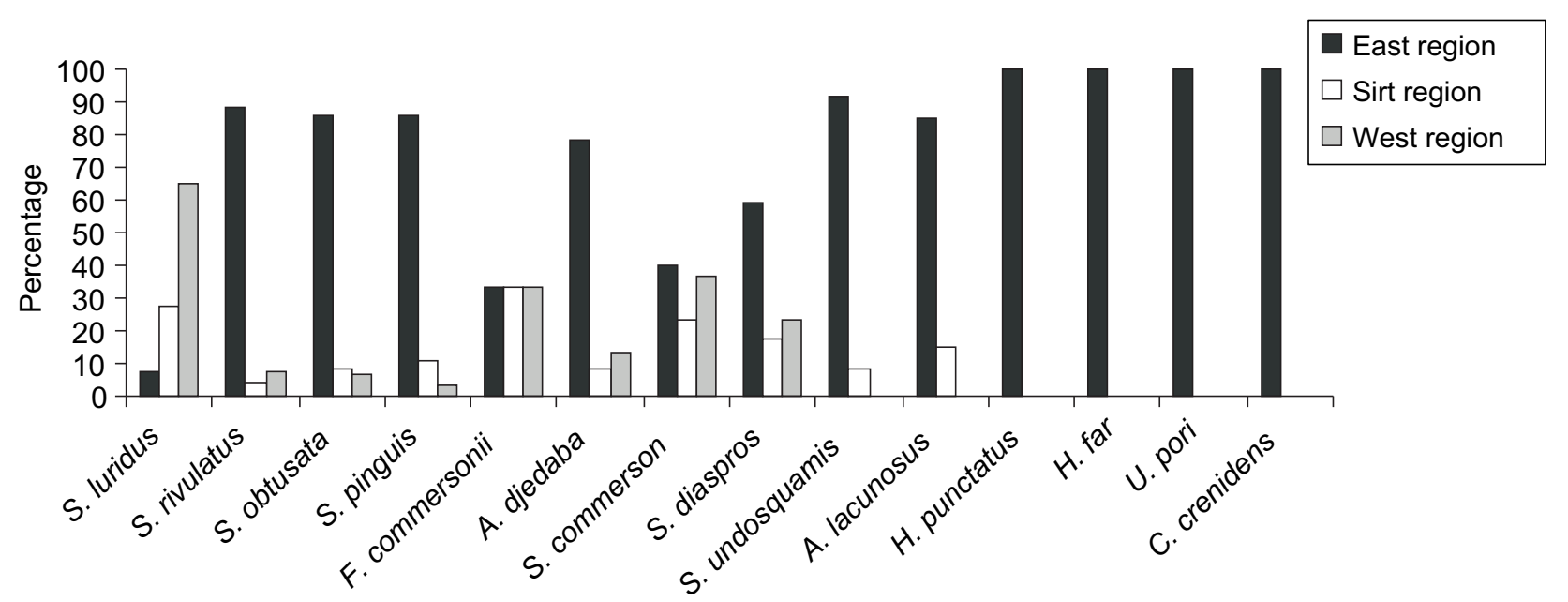

Fig. 4. The distribution in percentage of each Lessepsian fish species along the Libyan coast 


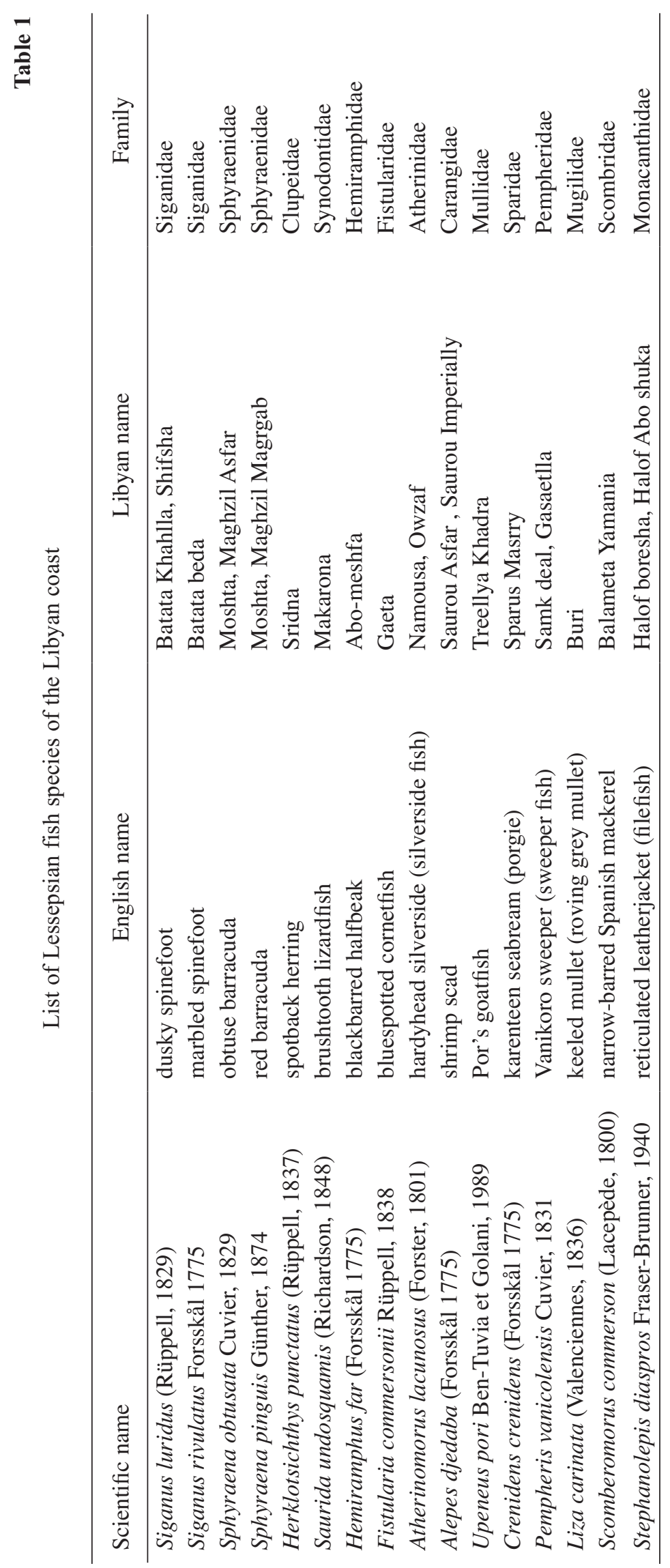


(Tripoli, Zwara); these were considered to be the most active sites for catches and were investigated monthly. Albardiah in the east region and Farwah in the west region were also selected as border sites and were investigated seasonally (Fig. 1) in order to standardize sampling bench-marks and fishing effort, two fishing boats of the same size and fishing gears were considered from each sampling site. A total of 4273 specimens were collected, including 1901 specimens of $S$. luridus, 1885 specimens of S. rivulatus, and 487 specimens of fourteen other Lessepsian fish species. The samples were immediately washed with fresh water, and were identified using Whitehead et al. (1984-1986) and Golani et al. (2002). Specimens from each sample were kept in a solution of formaldehyde and ethanol mixture. The samples were subsequently washed with fresh water and stored in 5-\% formaldehyde. Standard morphometric measurements and meristic counts were taken and documented. The abundance, habitat type, depth range, maximum size, and commercial value were recorded.

The abundance is divided into two levels: rare and common, according to Bilecenoglu and Taşkavak (2002). If the species is represented by less than $1 \%$ of the total Lessepsian fish collected during the fieldwork, the species is designated as rare. The general habitat type for each sample was classified as vegetated (including rocks with algae, sand with algae, and grass with algae), pelagic, rocky, and sandy. The sizes (maximum total lengths) were placed in three categories, as small $(\mathrm{TL}<10 \mathrm{~cm})$, medium $(10 \leq \mathrm{TL}<50 \mathrm{~cm})$, and large $(\mathrm{TL} \geq 50 \mathrm{~cm})$. The commercial value was based on commercial information received from the fishermen's union and was roughly divided into "commercial value" and "no commercial value".

Table 2

Morphological and meristic characters for Herklotsichthys punctatus and Liza carinata

\begin{tabular}{|c|c|c|c|c|c|c|c|}
\hline $\begin{array}{l}\text { Scientific } \\
\text { name }\end{array}$ & Coordinate & Number & $\begin{array}{l}\text { Total } \\
\text { length } \\
{[\mathrm{cm}]}\end{array}$ & Meristic & Habitat & $\begin{array}{c}\text { Average } \\
\text { Temperature } \\
{\left[{ }^{\circ} \mathrm{C}\right]}\end{array}$ & $\begin{array}{c}\text { Depth } \\
{[\mathrm{m}]}\end{array}$ \\
\hline H. punctatus & $\begin{array}{l}32^{\circ} 03^{\prime} 50^{\prime \prime} \mathrm{N} \\
23^{\circ} 59^{\prime} 02^{\prime \prime} \mathrm{E}\end{array}$ & 1 & 7.2 & $\mathrm{D} 15, \mathrm{~A} 17, \mathrm{P} 16, \mathrm{~V} 8$ & Pelagic & 15 & $1-3$ \\
\hline L. carinata & $\begin{array}{l}32^{\circ} 04^{\prime} 43^{\prime \prime} \mathrm{N} \\
23^{\circ} 58^{\prime} 50^{\prime \prime} \mathrm{E}\end{array}$ & 2 & $16.3-23.3$ & $\begin{array}{c}\mathrm{D} 1, \mathrm{IV}, \mathrm{D} 21+8 \\
\mathrm{~A} \mathrm{III}+9 \mathrm{P} 15, \mathrm{~V} \mathrm{I}+5\end{array}$ & Pelagic & 17 & $5-7$ \\
\hline
\end{tabular}

Table 3

Abundance and habitat occupation for each species according to the main regions

\begin{tabular}{lccccccc}
\hline & & \multicolumn{7}{c}{ Regions } \\
\cline { 3 - 8 } Species & Habitat & \multicolumn{2}{c}{ West Region } & \multicolumn{2}{c}{ Sirt Region } & \multicolumn{2}{c}{ East Region } \\
\cline { 3 - 8 } & & $\%$ & abundance & $\%$ & abundance & $\%$ & abundance \\
\hline S. luridus & Vegetation & 87.74 & Common & 81.27 & Common & 6.52 & Common \\
S. rivulatus & Vegetation & 9.91 & Common & 11.46 & Common & 75.18 & Common \\
S. obtusata & Pelagic & 0.21 & Rare & 0.77 & Rare & 2.43 & Common \\
S. pinguis & Pelagic & 0.36 & Rare & 3.41 & Common & 7.82 & Common \\
H. punctatus & Pelagic & - & - & - & - & 0.04 & Rare \\
S. undosquamis & Sandy & - & - & 0.31 & Rare & 0.99 & Rare \\
H. far & Pelagic & - & - & - & - & 3.24 & Common \\
F. commersonii & Sandy & 0.07 & Rare & 0.15 & Rare & 0.04 & Rare \\
A. lacunosus & Sandy & - & - & 0.46 & Rare & 0.76 & Rare \\
A. djedaba & Pelagic & 0.36 & Rare & 0.62 & Rare & 1.62 & Common \\
U. pori & Sandy & - & - & - & - & 0.09 & Rare \\
C. crenidens & Sandy & - & - & - & - & 0.09 & Rare \\
$P$. vanicolensis & Rocky & - & - & - & - & 0.09 & Rare \\
L. carinata & Pelagic & - & - & - & - & 0.09 & Rare \\
S. commerson & Pelagic & 1.07 & Common & 1.08 & Common & 0.54 & Rare \\
S. diaspros & Rocky & 0.29 & Rare & 0.46 & Rare & 0.45 & Rare \\
Total & & 100 & & 100 & & 100 & \\
\hline
\end{tabular}

- species absent. 


\section{RESULTS}

A total of 16 Lessepsian fish species were found (Table 1). Two of them are recorded for the first time on the Libyan coast: $H$. punctatus (Rüppell, 1837) and L. carinata (Valenciennes, 1836). Their morphological and meristic characters are given (Table 2). The species names Sphyraena obtusata Cuvier, 1829 and S. pinguis Günther, 1874 are consistent with those provided by Doiuchi and Nakabo (2005) in their recent revision.

As regards the abundance, the majority (9) of the Lessepsian fish species studied $(56.25 \%)$ were rare, constituting fewer than $1 \%$ of the total number of the Lessepsian fish collected, while the remaining seven species $(43.75 \%)$ were common. In terms of the habitat occupation, the fish were found on vegetation $(12.5 \%)$, in the water column (=pelagic; $43.75 \%$ ), on sandy bottom $(31.25 \%)$, and on rocky bottom $(12.5 \%)$.

According to size, $75 \%$ of the Lessepsian species were categorized as medium, followed by small $(6.25 \%)$, and large (18.75\%). More than one-third (37.5\%), were species known for their commercial value, whilst $62.50 \%$ were species with no commercial value (Fig. 2).

Regarding the distribution, the $50 \%$ of the fishes surveyed were caught along the entire Libyan coast, $37.5 \%$ in the eastern part, and $12.5 \%$ in the east and central part (Fig. 3).

The abundance and the habitat occupation of the species in each of the main regions are presented in Table 3. The commercial value, size, and distribution of the species in each of the main regions are presented in Table 4. Fig. 4 illustrates the distribution of each species along the Libyan coast.

\section{DISCUSSION}

Sixteen Lessepsian fish species were found, two of them are additions to the Libyan fish fauna and are also additions to the list of Lessepsian fish migrants in Libya: H. punctatus (Rüppell, 1837) and L. carinata (Valenciennes, 1836) (Tables 1, 2). These species have been recorded in many areas of the eastern Mediterranean Sea by Kosswig (1956), Mouneimné (1977), Whitehead et al. (1984-1986) and El-Sayed (1994). When a species is found to be rare, or as single specimen only, this is considered to be the first step in establishing a successful population, as expressed by an increase in the population (Golani and Ben-Tuvia 1989). Three species have also been recorded from Libya by other authors: Parexocoetus mento (Valenciennes, 1846) (cf. Ben-Tuvia 1966), Sargocentron rubrum (Forsskål, 1775), and Upeneus moluccensis (Bleeker, 1855) (cf. Stirn 1970), but they were not found during the present study.

The abundance indicates that seven species can be considered as common, namely Siganus luridus; S. rivulatus; Sphyraena obtusata Cuvier, 1829; Alepes djedaba (Forsskål 1775); Hemiramphus far (Forsskål 1775); Sphyraena pinguis; Scomberomorus commerson (Lacepède, 1800) (43.75\%), while most of the Lessepsian fish species were rare, such as Fistularia commersonii; Stephanolepis diaspros Fraser-Brunner, 1940; Herklotsichthys punctatus (Rüppell, 1837); Upeneus pori Ben-Tuvia et Golani, 1989; Crenidens crenidens (Forsskål 1775); Pempheris vanicolensis; Liza carinata (Valenciennes, 1836); Saurida undosquamis (Richardson, 1848); and Atherinomorus lacunosus (Forster, 1801) (56.25\%) (Fig. 2). The abundance of these species differs between the main regions (Table 3 ), which may be due to a relation between the species' early

Table 4

The size, commercial value, and distribution of each species according to the main regions

\begin{tabular}{|c|c|c|c|c|c|c|c|}
\hline \multirow[b]{3}{*}{ Species } & \multicolumn{7}{|c|}{ Regions } \\
\hline & \multirow{2}{*}{$\begin{array}{l}\text { Size } \\
{[\mathrm{cm}]}\end{array}$} & \multicolumn{2}{|c|}{ West Region } & \multicolumn{2}{|c|}{ Sirt Region } & \multicolumn{2}{|c|}{ East Region } \\
\hline & & Distribution & $\begin{array}{c}\text { Commercial } \\
\text { value }\end{array}$ & Distribution & $\begin{array}{c}\text { Commercial } \\
\text { value }\end{array}$ & Distribution & $\begin{array}{c}\text { Commercial } \\
\text { value }\end{array}$ \\
\hline S. luridus & Medium & + & Commercial & + & Commercial & + & Commercial \\
\hline S. rivulatus & Medium & + & None & + & Commercial & + & Commercial \\
\hline S. obtusata & Large & + & None & + & None & + & None \\
\hline S. pinguis & Medium & + & None & + & None & + & Commercial \\
\hline H. punctatus & Small & - & - & - & - & + & None \\
\hline S. undosquamis & Medium & - & - & + & None & + & None \\
\hline H. far & Medium & - & - & - & - & + & Commercial \\
\hline F. commersonii & Large & + & None & + & None & + & None \\
\hline A. lacunosus & Medium & - & - & + & None & + & None \\
\hline A. djedaba & Medium & + & None & + & None & + & Commercial \\
\hline$U$. pori & Medium & - & - & - & - & + & None \\
\hline C. crenidens & Medium & - & - & - & - & + & None \\
\hline P. vanicolensis & Medium & - & - & - & - & + & None \\
\hline L. carinata & Medium & - & - & - & - & + & None \\
\hline S. commerson & Large & + & Commercial & + & Commercial & + & Commercial \\
\hline S. diaspros & Medium & + & None & + & None & + & None \\
\hline
\end{tabular}

+ present, - absent. 
arrival and the species abundance. Golani (1998) showed that there is a correlation between species that arrived earlier in the Mediterranean and their greater abundance. This can be explained by (a) the longer they are in the Mediterranean, the greater the opportunity for them to build up their populations, or (b) the greater research effort, which was much less intense in the past (Golani 2002). On the Turkish coast, the abundance of the Lessepsian fish has the following proportions: 5 species $(15 \%)$ are categorized as rare and the remaining 28 species (84.8\%) as common (Bilecenoglu and Taşkavak 2002). The proportions are different in the presently reported study.

Regarding habitat occupation, the majority of the Lessepsian migrant fish species were found in the coastal area and usually at depths of 1-50 m (Fig. 2, Table 3), while only two species were found in the vegetation habitat, namely $S$. rivulatus and S. luridus $(12.5 \%)$. S. rivulatus was found in several different overgrown habitats (rocks with algae, sand with algae, and grass with algae) whereas $S$. luridus was found in one specific vegetation habitat (rocks with algae). Both Siganus species are considered to be strictly herbivorous, and in the Mediterranean only two fish species belong to a similar trophic guild-Sarpa salpa (L.) (Sparidae) and Sparisoma cretense (L.) (Scaridae) - both in the eastern and central basins (Azzurro and Andaloro 2004). Bariche et al. (2004) showed that $S$. rivulatus is able to settle on a large range of substrates and habitats, including rock pools, muddy harbours, and sea-grass beds. In the eastern Mediterranean, S. rivulatus has a wider settlement range than that of $S$. luridus, probably due that $S$. rivulatus has benefited from the low diversity of native herbivorous species (Bariche et al. 2004). Five species were found in the sand habitat: S. undosquamis, F. commersonii, A. lacunosus, $U$. pori, and C. crenidens $(31.25 \%)$, and two species were on rocks: $P$. vanicolensis and $S$. diaspros $(12.5 \%)$. The many potential rock habitat site-related species from the Red Sea would not succeed, or would only rarely succeed, in reaching that habitat in the Mediterranean, since they would need to cross the Suez Canal, the northern Gulf of Suez and the south-eastern Mediterranean, all of which lack a continuous rocky habitat (Golani 2002). The pelagic species are the largest category (seven species): S. obtusata, S. pinguis, H. punctatus, H. far, A. djedaba, L. carinata, and S. commerson $(43.8 \%)$. The majority of these species tend to spread within a depth range of 20 to $40 \mathrm{~m}$ (Por 1978).

As regards of their size, twelve species $(75 \%)$ were classified as medium, followed by three species considered large $(18.75 \%)$ and one species-small (6.25\%) (Fig. 2, Table 4). This result is similar to the results in the Turkish seas, where $78.8 \%$ of species were medium-sized, followed by large (12.5\%) and small (9.1\%) (Bilecenoglu and Taşkavak 2002). However, these figures differ from the results in the eastern Mediterranean where more than half of the Lessepsian migrants were of medium size; small- and large species were more or less equal in number (13 and 12, respectively) (Golani 2002).
As far as their commercial value is concerned, six species $(37.5 \%)$ have become commercially valuable on the Libyan coast, and ten species (62.5\%) are characterized as having no commercial value (Fig. 2). Of these six, three ( $S$. pinguis, $H$. far, and $A$. djedaba) were found in the east part of the Libyan coast, two (S. luridus, S. commerson) all along the Libyan coast, and one ( $S$. rivulatus) in the east part and the Sirt Gulf only (Table 4). These species are now found regularly in the Libyan catches; most of them have been recorded as commercially valuable in many areas in the eastern and central-south Mediterranean Sea (Torcu and Mater 2000, Bilecenoglu and Taşkavak 2002, Golani 2002, Shakman and Kinzelbach 2006).

The distribution observed, implies that half of the species (50\%) are present all along the Libyan coast (Fig. 3). There is a different concentration for the different species: $S$. luridus is concentrated more in the west part and the Sirt Gulf rather than in the east part of the Libyan coast, whilst S. rivulatus is concentrated in the east part and decreases in the Sirt Gulf and the west part (Fig. 4). There may be competition between $S$. luridus and $S$. rivulatus in the east region, as these species together are less concentrated in the area from Zwara up to the Tunisian border, although there is an appropriate habitat for herbivorous species in this area especially on the Farwah coast. Two species are distributed in the east part and Sirt Gulf $(S$. undosquamis, A. lacunosus) and six species are distributed only in the east part (H. punctatus, H. far, U. pori, $C$. crenidens, P. vanicolensis, L. carinata) (Fig. 4). For a better understanding of Lessepsian immigration, additional taxonomic and biological investigations are required (Ben-Tuvia, 1978). It is expected that in some cases the exchange of fauna and flora may have taken place before the opening of the Suez Canal, as a result of the elevation of sea levels and undulations of the Isthmus during the Pleistocene (Ben-Tuvia 1978).

The presently reported study has shown that some of the Lessepsian migrants have successfully adapted to the different topography and environments of Libyan coast and two fish species are also recorded for the first time. Many species have become widespread along this coast, which means that they are contributing to the commercial fish catch in Libya.

\section{ACKNOWLEDGEMENTS}

We would like to thank the Administration of the Marine Biology Research Center (MBRC) in Libya (Mr. Noureddin Essarbout, Head of the Center, and Abdulbaset Abuissa, Head of Studies and Consultation Director) for their support of this study. We would also like to thank the fishermen and the fishermen's union for their collaboration with us. We would like to express our thanks to Dr. H. Winkler (Zoology Institute, Rostock University, Germany) for his advice and to Dr. A. Pont, London, for the linguistic revision of the text. This article constitutes a part of a PhD project. 


\section{REFERENCES}

Akyol O., Ünal V., Ceyhan T., Bilecenoglu M. 2005. First record of Lagocephalus sceleratus (Gmelin, 1789), in the Mediterranean Sea. Journal of Fish Biology 66: 1183-1186.

Al-Hassan L.A.J., El-Silini O.A. 1999. Check-list of bony fishes collected from the Mediterranean coast of Benghazi, Libya. Revista de Biología Marina y Oceanografía 34: 291-301.

Azzurro E., Andaloro F. 2004. A new settled population of the Lessepsian migrant Siganus luridus (Pisces: Siganidae) in Linosa Island-Sicily Strait. Journal of the Marine Biological Association of the United Kingdom 84: 819-821.

Azzurro E., Pizzicori P., Andaloro F. 2004. First record of Fistularia commersonii (Fistularidae) from the central Mediterranean. Cybium 28 (1): 72-74.

Bariche M., Letourneur Y., Harmelin-Vivien M. 2004. Temporal fluctuations and settlement patterns of native and Lessepsian herbivorous fishes on the Lebanese coast (eastern Mediterranean). Environmental Biology of Fishes 70: 81-90.

Ben-Souissi J., Zaouali J., Bradai M.N., Quignard J.P. 2004. Lessepsian migrant fishes off the coast of Tunisia. First record of Fistularia commersonii (Osteichthyes, Fistularidae) and Parexocoetus mento (Osteichthyes, Exocoetidae). Vie et Milieu 54: 247-248.

Ben-Tuvia A. 1966. Red sea fishes recently found in the Mediterranean. Copeia 2: 254-275.

Ben-Tuvia A. 1976. Occurrence of Red Sea fishes Herklotsichthys punctatus, Autisthes puta and Rhonciscus stridens in the eastern Mediterranean. Israel Journal of Zoology 25: 212-213.

Ben-Tuvia A. 1978. Immigration of fishes through the Suez Canal. Fishery Bulletin 76: 249-255.

Bilecenoglu M., Kaya M. 2006. A new alien fish in the Mediterranean Sea - Platax teira (Forsskål, 1775) (Osteichthyes: Ephippidae). Aquatic Invasions 1: 80-83.

Bilecenoglu M., Kaya M., Akalin S. 2006. Range expansion of silverstripe blaasop, Lagocephalus sceleratus (Gmelin, 1789), to the northern Aegean Sea. Aquatic Invasions 1: 289-291.

Bilecenoglu M., Taşkavak E. 2002. Characterization of Lessepsian migrant fish at Turkish sea. Pp. 87-91. In: Öztürk B., Basusta N. (eds.) Workshop on Lessepsian migration, 20-21 July 2002, Gökceada, Turkey.

Bn 'Abd al-lh 'R., Al-Trky -., Ftywry ' [Ben-Abdallah A.R., Alturky A., Fituri A.] 2005. Tsjylāt lb'ad alāsm-k al-dkhylh,t fy al-sh-ty al-lyby. [Records of exotic fishes in the Libyan coast.] Mjlh,t ' lwm Al-bh-r [Libyan Journal of Marine Science] 10: 1-8. [In Arabic.]

Bradai M.N., Quignard J.-P., Bouain A., Jarboui O., Ouannes-Ghorbel A., Ben Abdallah L., Zaouali J., BenSalem S. 2004. Ichtyofaune autochtone et exotique des côtes Tunisiennes: Recensement et biogéographie. Cybium 28: 315-328.

Çinar M.E., Bilecenoglu M., Öztürk B., Can A. 2006. New records of alien species on the Levantine coast of Turkey. Aquatic Invasions 1: 84-90.

Corsini M., Margies P., Kondilatos G., Economidis P.S. 2006. Three new exotic fish records from the SE Aegean Greek waters. Scientia Marina 70: 319-323.
Doiuchi R., Nakabo T. 2005. The Sphyraena obtusata group (Perciformes: Sphyraenidae) with a description of a new species from southern Japan. Ichthyological Research 52: 132-151.

Dulcic J., Pallaoro A. 2004. First record of the marbled spinefoot Siganus rivulatus (Pisces: Siganidae) in the Adriatic Sea. Journal of the Marine Biological Association of the United Kingdom 84: 1087-1088.

El-Sayed R.S. 1994. Check-list of Egyptian Mediterranean fishes. National Institute of Oceanography and Fisheries, Alexandria, Egypt.

Golani D. 1998. Impact of Red Sea fish migrants through the Suez Canal on the aquatic environment of the eastern Mediterranean. Bulletin of the Yale School of Forestry and Environmental Studies 103: 375-387.

Golani D. 2002. Lessepsian fish migration - Characterization and impact on the Eastern Mediterranean. Pp. 1-9. In: Öztürk B., Basusta N. (eds.) Workshop on Lessepsian migration, 20-21 July 2002, Gökceada, Turkey.

Golani D. 2006. The Indian scad (Decapterus russelli), (Osteichthyes: Carangidae), a new Indo-Pacific fish invader of the eastern Mediterranean. Scientia Marina 70: 603-605.

Golani D., Ben-Tuvia A. 1989. Characterization of Lessepsian (Suez Canal) fish migrants. Pp. 235-243. In: Spanier E., Steinberger Y., Luria M. (eds.) Environmental Quality and Ecosystem Stability. Jerusalem, Israel.

Golani D., Orsi-Relini L., Massuti E., Quignard J.-P. 2002. CIESM Atlas of Exotic species in the Mediterranean. Vol. 1. Fishes. CIESM publishers, Monaco.

Golani D., Sonin O. 2006. The Japanese threadfin bream Nemipterus japonicus, a new Indo-Pacific fish in the Mediterranean Sea. Journal of Fish Biology 68: 940-943.

Kosswig C. 1956. Facts and problems offered by the Erythrean invaders into the Mediterranean. Balık et Balıkçılık (Istanbul) 4 (9): 31-37.

Ktari-Chakroun F., Boualal M. 1971. Capture de Siganus luridus (Rüppell, 1829) dans le golf de Tunis. Bulletin de l'Institut national scientifique et technique d'Océanographie et de pêche de Salammbô 2: 49-52.

Ktari F., Ktari M.H. 1974. Présence dans le Golf de Gabès de Siganus luridus (Rüppell, 1829) et de Siganus rivulatus (Forsskål, 1775) (Poissons, Siganidae) parasités par Pseudohaliotrematodides polymorphus. Bulletin de 1'Institut national scientifique et technique d'Océanographie et de pêche de Salammbô 3: 95-98.

Mouneimné N. 1977. Liste des poissons de la côte du Liban (Méditerranée orientale). Cybium 1: 37-66.

Pallaoro A., Dulčić J. 2001. First record of the Sphyraena chrysotaenia (Klunzinger, 1884) (Pisces, Sphyraenidae) from the Adriatic Sea. Journal of Fish Biology 59: 179-182.

Papaconstantinou C. 1990. The spreading of Lessepsian fish migrants into the Aegean Sea (Greece). Scientia Marina 54: 313-316.

Por F.D. 1978. Lessepsian migration. Ecological studies. Springer Verlag, Berlin.

Shakman E.A., Kinzelbach R. 2006. Halfbeak fish Hemiramphus far (Forsskål, 1775) in coastal waters of Libya. Zoology in the Middle East (Heidelberg) 39: 111-112. 
Shakman E.A., Kinzelbach R. 2007. First record of the sweeper fish Pempheris vanicolensis Cuvier, 1821 in the eastern part of the Libyan coast. Rostocker Meereskundliche Beiträge 18: 1-3.

Stirn J. 1970. Some notes on western trends of Lessepsian migration. Pp. 187-190. Journées Ichthyologiques, Rome, 30 Nov.-1 Dec., CIESM, Monaco.

Torcu H., Mater S. 2000. Lessepsian fishes spreading along the coasts of the Mediterranean and the Southern Aegean Sea of Turkey. Turkish Journal of Zoology 24: 139-148.
Whitehead P.J.P., Bauchot M.L., Hureau J.C., Nielsen J., Tortonese E. (eds.) 1984-1986. Fishes of the north-eastern Atlantic and the Mediterranean. Vols. I, II, III, UNESCO, Paris.

Zupanovic S., El-Buni A.A. 1982. A contribution to demersal fish studies off the Libyan coast. Bulletin of Marine Research Centre (Tripoli-Libya) 3: 77-122.

Received: 15 February 2007 Accepted: 9 May 2007 Published electronically: 15 July 2007 